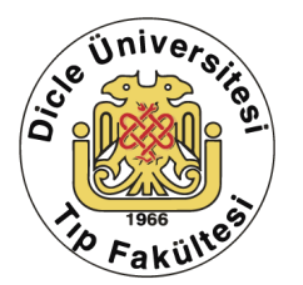

www.diclemedj.org

Özgün Araștırma / Original Article

\title{
Normotermik Kardiyopulmoner Bypass Sırasında Enflamasyon Parametrelerindeki Değişiklikler İle Oksidatif Stresin Değerlendirilmesi
}

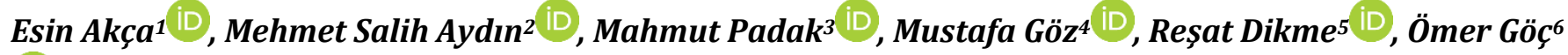
(iD)

1 Şişli Hamidiye Etfal Eğitim ve Araştırma Hastanesi, Kalp ve Damar Cerrahisi Anabilim Dalı İstanbul, Türkiye 2 Harran Üniversitesi, Tıp Fakültesi, Kalp Damar Cerrahi Anabilim Dalı, Şanlıurfa, Türkiye

3 Harran Üniversitesi, Sağlık Hizmetleri Meslek Yüksekokulu, Perfüzyon Teknikleri Programı, Şanlıurfa, Türkiye 4 Özel Meydan Hastanesi, Kalp Damar Cerrahi Anabilim Dalı, Şanlıurfa, Türkiye

5 Harran Üniversitesi, Sağlık Hizmetleri Meslek Yüksekokulu, Perfüzyon Teknikleri Programı, Şanlıurfa, Türkiye

6 Harran Üniversitesi, Sağllk Hizmetleri Meslek Yüksekokulu, Biyomedikal Cihaz Teknolojileri, Sanlıurfa, Türkiye

Geliş: 29.07.2019; Revizyon: 19.11.2019; Kabul Tarihi: 21.01.2020

$\ddot{0} \mathbf{z}$

Amaç: Bu çalışmanın amacı, kardiyopulmoner bypass (KPB) ameliyatına giren hastalardan belirli aralıklarla alınan kanın serumundaki CRP, seruloplazmin ve TAS (total antioksidan seviye), TOS (total oksidan seviye), OSİ (oksidatif stres indeksi) seviyelerini ölçerek bir değerlendirmenin yapılması amaçlanmıştır.

Yöntemler: Çeşitli sebeplerden dolayı KPB cerrahisi ile ameliyat olan hastalardan ameliyat öncesi, pompaya (kalp akciğer makinesi) giriş, kross klemp sonrası ve protamin verilmesi sonrası olmak üzere 4 jelsiz tüpe kan alınarak bir çalışma grubu oluşturulmuştur. Alınan kanlar santrifüjde ayrıştırıldıktan sonra plazmaları $-80^{\circ} \mathrm{C}$ 'de saklanmıştır. Numuneler çalışma gününde otoanalizör cihazında çözülerek serum Seruloplazmin, C-Reaktif Protein (CRP), TAS, TOS ve OSİ kolorimetrik yöntemle ölçülmüştür.

Bulgular: TAS değeri; ameliyat öncesi $0.95 \pm 0.19$, pompaya giriş $0.73 \pm 0.13$, kross klemp sonrası $0.84 \pm 0.18$, protamin sonrası $0.92 \pm$ 0.14 ve $\mathrm{p}<0,001$, TOS değeri sırasıyla; $12.66 \pm 3.21,10.22 \pm 3.28,19.04 \pm 6.00,25.88 \pm 8.14$ ve p <0,001, 0Sİ; 1,35 $\pm 0.35,1.48 \pm 0.74$, $2.38 \pm 0.91,2.81 \pm 0.80$ ve $p<0,001$, Seruloplazmin; $1002,48 \pm 209,20,554.71 \pm 125.77,581.92 \pm 156.67,633.79 \pm 166.69$ ve $p<0,001$, CRP; $0.85 \pm 1.44,0.51 \pm 1.09,0.35 \pm 0.44,0.47 \pm 0.89$ ve $\mathrm{p}=0.291$ olarak bulunmuştur.

Sonuç: Bu çalışma sonucunda TAS, TOS, OSİ ve seruloplazmin düzeyleri gruplar arasında istatistiksel açıdan anlamlı bir fark bulunmuştur $(\mathrm{p}<0,001)$. Serum CRP düzeyleri gruplar arasında istatiksel açıdan anlamlı bir fark bulunamamıştır.

Anahtar kelimeler: Kardiyopulmoner baypas, İnflamasyon parametreleri, Oksidatif stres, CRP, Seruloplazmin.

DOI: $10.5798 /$ dicletip.706148

Yazıșma Adresi / Correspondence: Mahmut PADAK, Harran Üniversitesi, Sağlık Hizmetleri Meslek Yüksekokulu, Perfüzyon Teknikleri Programı,

Şanlıurfa, Türkiye,05435258563, mpadak@harran.edu.tr 


\title{
Evaluation Of Oxidative Stress With Changes In Inflamation Parameters During Normothermic Cardiopulmonary Bypass
}

\begin{abstract}
Objective: The aim of this study was to evaluate the levels of CRP, ceruloplasmin and TAS (total antioxidant level), TOS (total oxidant level), OSI (oxidative stress index) levels in blood serum taken from patients undergoing cardiopulmonary bypass (CPB).
\end{abstract}

Methods: A study group was formed by taking 4 gel-free strains of blood from pre-operative, pump (cardiopulmonary machine) entry, cross-clamping and after protamine administration from patients who underwent surgery with CPB for various reasons. Plasma samples were stored at -80 [deg.] $\mathrm{C}$ after removal of the blood from the centrifuge. The samples were dissolved in the autoanalyzer on the study day and serum Seruloplasmin, C-Reactive Protein (CRP), TAS, TOS and OSI were measured by colorimetric method.

Results: TAS value; $0.95 \pm 0.19$ preoperatively, $0.73 \pm 0.13$ at the pump, $0.84 \pm 0.18$ after cross clamping, $0.92 \pm 0.14$ after the protamine and $\mathrm{p}<0.001$, TOS value respectively; $12.66 \pm 3.21,10.22 \pm 3.28,19.04 \pm 6.00,25.88 \pm 8.14$ and $\mathrm{p}<0.001$, OSI; $1.35 \pm 0.35,1.48 \pm 0.74,2.38 \pm 0.91,2.81 \pm 0.80$ and $p<0.001$, Seruloplasmin; 1002, $48 \pm 209,20,554.71 \pm 125.77$, $581.92 \pm 156.67,633.79 \pm 166.69$ and $p<0.001, \mathrm{CRP} ; 0.85 \pm 1.44,0.51 \pm 1.09,0.35 \pm 0.44,0.47 \pm 0.89$ and $\mathrm{p}=0.291$ respectively.

Conclusions: As a result of this study, statistically significant differences were found between TAS, TOS, OSI and ceruloplasmin levels in the groups $(\mathrm{p}<0.001)$. Serum CRP levels were not statistically significant between the groups.

Keywords: Cardiopulmonary Bypass, Inflammatory Parameters, Oxidative Stress, CRP, Seruloplasmin.

\section{GíRiş}

Kardiyopulmoner bypass (KPB), kalbin ve akciğerlerin fonksiyonlarını belirli bir süre için yerine getiren kalp-akciğer makinesi kullanılarak yapılan kalp hastalıklarının cerrahi tedavi işlemidir. KPB sırasında kanın, biyouyumlu olmayan ekstrakorporeal dolaşım devre elemanlarının yüzeyine teması ile birlikte pihtılaşma bozukluğu, kan hücreleri ve plazma proteinlerinin hasarl, iskemi-reperfüzyon hasarı, enflamasyon ve oksidatif stres gibi istenmeyen yan etkiler de meydana gelebilmektedir.

Kardiyopulmoner bypass esnasında oluşan enflamasyonun etkisi ile birçok kan parametresi değişmekte ve değişen parametreler de olumsuz sonuçlar doğurabilmektedir. Bu parametreler arasında yer alan fetuin-A (alpha-2-Heremans Schmid glikoprotein), C-Reaktif Protein (CRP) ve kalsiyum (Ca) vasküler kalsifikasyonda da önemlidir. Arteriyel duvarda biyoapatit formda kalsiyum fosfatın depolanması olarak tanımlanan vasküler kalsifikasyon kardiyovasküler hastalığın mortalitesi ile yüksek oranda ilişkilidir ${ }^{1,2}$. Serum Ca ve fosfat konsantrasyonunun yüksek seviyede olmasının vasküler kalsifikasyonu önemli derecede arttırdığını öne süren çalışmalar mevcuttur ${ }^{3}$.

İnsan serumunda bulunan kalsifikasyonun inhibitörlerinden biri olan fetuin-A, fetal gelişim esnasında birçok dokudan üretilmesine rağmen erişkin dönemde karaciğerden sentezlenen 59 $\mathrm{kDa}$ glikoproteindir². Ayrıca fetuin-A'nın kardiyomiyositlerde iskemiye karşı koruyucu etkisi olduğu da belirtilmiștir ${ }^{3}$. Lebreton ve arkadaşları; travma ve enflamasyon boyunca fetuin-A konsantrasyonunun azaldığını göstermiştir ${ }^{4}$.

Serum CRP yoğunluğu kalp damar hastalıkları hastalık risk değerlendirmesinde kullanılan parametrelerden biridir ve artış göstermesi proenflamasyonu gösterir. CRP, dolaşım esnasında artmış olan proinflamatuar 
sitokinlere karaciğerin verdiği bir cevap olabilmektedir ve birçok faktör yüksek CRP düzeylerinden sorumludur. CRP düzeyinin yüksek olmasının bir diğer sebebi ise renal yetmezliğin ilerlemesine bağlı artan sıvı fazlalığı ve kronik kalp yetmezliğidir. Yapılan birçok araştırmada serum fetuin-A ile CRP'nin arasında ters bir ilişkinin olduğu da rapor edilmiştir ${ }^{5-7}$.

Bir diğer enflamasyon parametrelerinden biri olan seruloplazmin, serumda bakırın \%90'ının bağlı bulunduğu ve oksidaz aktivitesi ile özellikle demir metabolizmasında rol oynayan bir protein olup; enflamasyon sırasında seviyesi artmaktadır ${ }^{8}$. İnsan vücudunda oluşan reaktif oksijen türleri (ROS) ile antioksidan savunma mekanizmaları fizyolojik şartlarda bir denge halindedir. Aşırı üretilen ROS ya da antioksidan savunmanın azalması, biyomoleküllerde yapısal ve fonksiyonel değişikliklere yol açarak oksidatif stresin oluşmasına neden olmaktadır ${ }^{9,10}$.

Enflamasyon ile oksidatif stres normalin üzerine çıktığı zaman, organizma bu duruma uyum sağlayacak şekilde yanıt vermektedir. Oksidatif stresin boyutlarının oldukça fazla olması ya da yanıtın yetersiz kalması durumunda oksidatif hasar oluşmaktadır. Bu da proteinler, lipidler ve nükleik asitler gibi biyomoleküllerin oksidasyonuna ve hücre membranı başta olmak üzere çeşitli hücre elemanlarında oksidatif harabiyetin oluşmasına sebep olmaktadır ${ }^{11-13}$.

$\mathrm{Bu}$ çalışmadaki amacımız kardiyovasküler cerrahiyi olanaklı kılan kardiyopulmoner bypass yönteminde belirli aralıklarla alınan kanın serumunda bulunan CRP, seruloplazmin ve TAS (total antioksidan seviye), TOS (total oksidan seviye), OSİ (Oksidatif Stres İndeksi) seviyelerini ölçmek ve farklı zamanlarda alınan bu kanlar arasında nasıl bir değişim olduğu araştırmaktır.

\section{YÖNTEMLER}

Hastalardan alınan bu dört farklı zamandaki kanlar santrifüjde ayrıştırıldıktan sonra plazmaları $-80{ }^{\circ} \mathrm{C}^{\prime}$ de saklandı. Numuneler çalışma gününde otoanalizör cihazında çözülerek serum Seruloplazmin, C-Reaktif Protein (CRP), TAS, TOS ve OSİ kolorimetrik yöntemle ölçülmüştür. Çalışmamızda Harran Üniversitesi Tıp Fakültesi Araştırma ve Uygulama Hastanesi Tibbi Biyokimya Laboratuvarı"nda rutin olarak kullanılan cihazlardan yararlanılmıştır.

$\mathrm{Bu}$ çalışma KPB kullanılarak elektif açık kalp cerrahisi (koroner arter greftleme, kapak replasmanı-tamiri) uygulanan 30 hasta üzerinde yapıldı. Çalışma için Klinik Araştırmalar Etik Kurulu onayı 02.07.2013 tarih 07 nolu oturum 13 sayılı kararı ile onay alındı. Tüm hastalar Helsinki Deklarasyonuna uygun olarak uygulanacak tedavi konusunda bilgilendirildi ve hastalardan bilgilendirilmiş onam formu alınd.

\section{a. Toplam Oksidan Seviye (TOS) Düzeyi Ölçümü}

Numunelerin toplam oksidan seviye (TOS) düzeyi, Rel Assay marka ticari kitlerden faydalanılarak ölçüm yapılmıştır. Ölçüm testin çalışma prensibinde örneklerin içerdiği oksidan moleküllerin ferroz iyonu ferrik iyona kümülatif olarak oksitlemesine dayanan, kolorimetrik yöntem kullanılmıştır. Sonuçlar $\mu$ mol H2O2 Equivalent/ L olarak ifade edildi14.

\section{b. Toplam Antioksidan Status (TAS) Düzeyi Ölçümü}

Numunelerinn total antioksidan seviye (TAS) düzeyi, Rel Assay marka ticari kitlerden faydalanılarak ölçüm yapılmıştır. Ölçüm için kullanılan yöntem örnekteki bütün antioksidan moleküllerin renkli ABTS* katyonik radikalini redüklemesi sonucu renkli radikalin antioksidan moleküllerin total konsantrasyonlarıyla orantılı olarak dekolorize olması prensibine dayanmaktadır. Kalibratör 
olarak E vitamininin suda çözünür bir analoğu olan Trolox kullanılır. Sonuçlar mmol Trolox Equivalent/L olarak ifade edilmiștir ${ }^{15}$.

\section{c. Oksidatif Stres İndeksi Ölçümü}

Oksidatif Stresin bir göstergesi olarak gösterilen Oksidatif Stres İndeksi (OSI), Toplam Oksidan Seviye (TOS) düzeylerinin Toplam Antioksidan Seviye (TAS) düzeylerine oranının yüzde derecesi olarak ifade edilir. Örneklerin Oksidatif Stres İndeksi (OSI) hesaplanırken TAS düzeyleri 10 ile çarpılarak TOS düzeyleri ile birimler eşitlenir ${ }^{16,17}$. Sonuçlar Arbutrary Units (AU) olarak ifade edilmiştir.

TOS, $\mu$ mol H2O2 Equiv. / L.

OSI $=$ $X 100$

TAS, $\mu$ mol trolox Equiv. / L.

\section{d. Seruloplazmin (Ferrooksidaz) Düzeyinin Ölçülmesi}

Seruloplazminin ferrooksidaz enzim aktivitesi erel metodu kullanılarak ölçülmüştür. $\mathrm{Bu}$ metod; ferroz demir iyonunun ferik demir iyonuna oksidasyonunu içermektedir. Sonuçlar $\mathrm{U} / \mathrm{L}$ olarak ifade edilmiştir ${ }^{18}$.

\section{e. CRP Düzeyinin Ölçülmesi}

Serum örneklerinin CRP düzeyleri Roche marka ticari kitlerle yine Roche Cobas İntegra 800 Biyokimya Otoanalizöründe kolorimetrik olarak çalışılmıştır. Sonuçlar mg/dL olarak ifade edilmiştir.

\section{f. İstatistiksel Analizler}

İstatistiksel analizler SPSS Versiyon 11.5 (SPSS Inc. Chicago USA) bilgisayar programı kullanılarak gerçekleștirilmiştir. Grupların ortalamaları arasındaki farkın önemi One-Way ANOVA testi ile karşılaștırılmıştır. Parametreler arasındaki ilişki Pearson korelasyon analizi ile araştırılmıştır. $\quad \mathrm{p}<0.05$ 'den küçük değerler istatistiksel olarak anlamlı kabul edilmiştir.

\section{BULGULAR}

Tablo 1'de görüldüğü gibi TAS düzeyleri gruplar arasında istatistiksel açıdan anlamlı bir fark bulunmuştur $(\mathrm{p}<0,001)$.

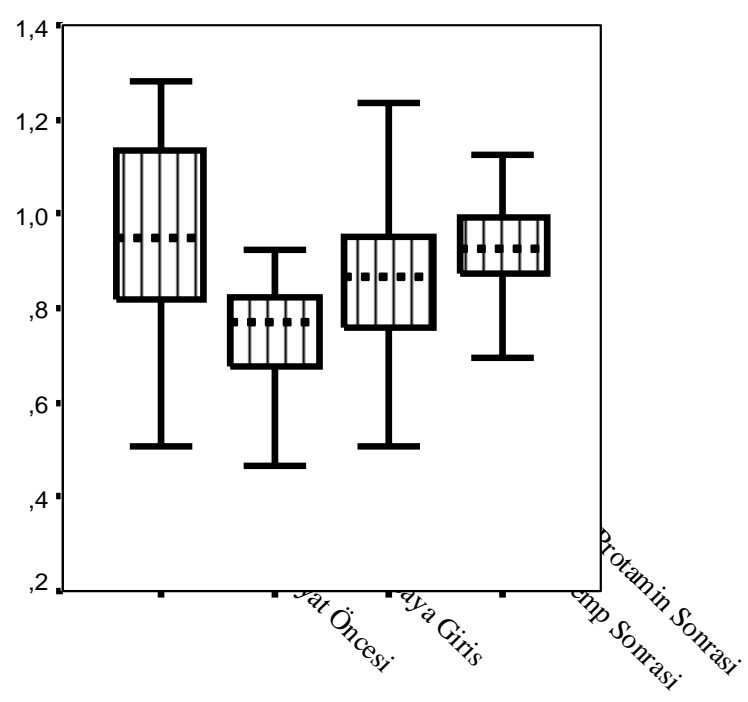

Şekil 1. Gruplar arasında TAS düzeylerinin fark, dağllım ve standart sapmaları

Pompaya giriş ile Ameliyat öncesi ve Protamin Sonrası TAS düzeyleri karşılaştırıldığında, serum örneklerinin içerdiği TAS düzeyleri diğer gruplara göre yüksek ve istatistiksel açıdan ileri düzeyde anlamlı bir fark olduğu bulunmuştur $(\mathrm{p}<0,001)$. Ameliyat öncesi TAS düzeyi ile Kros Klemp sonrası TAS düzeyi karşılaştırıldığında diğer gruplara göre orta düzeyde anlamlı bir fark görülmüștür $(p<0,010)$. Pompaya giriş ile Kros Klemp sonrası örneklerinin TAS düzeyleri karșllaştırıldığında serum örneklerinin içerdiği TAS düzeyi düşük olup anlamlı bir fark görülmüştür $(\mathrm{p}<0.050)$.

Numunelerin içerdiği TOS düzeyleri incelendiğinde gruplar arasında anlamlı bir fark bulunmuştur $(\mathrm{p}<0,001)$. Ameliyat Öncesi ile Kros Klemp Sonrası ve Protamin sonrası serum TOS düzeyleri karşılaștırıldığında, numunelerin içerdiği TOS düzeyi diğer grupların düzeyleri ile karşılaştırıldığında istatistiksel açıdan düşük ve ileri düzeyde anlamlı olduğu gözlemlenmiştir $(\mathrm{p}<0,001)$. 


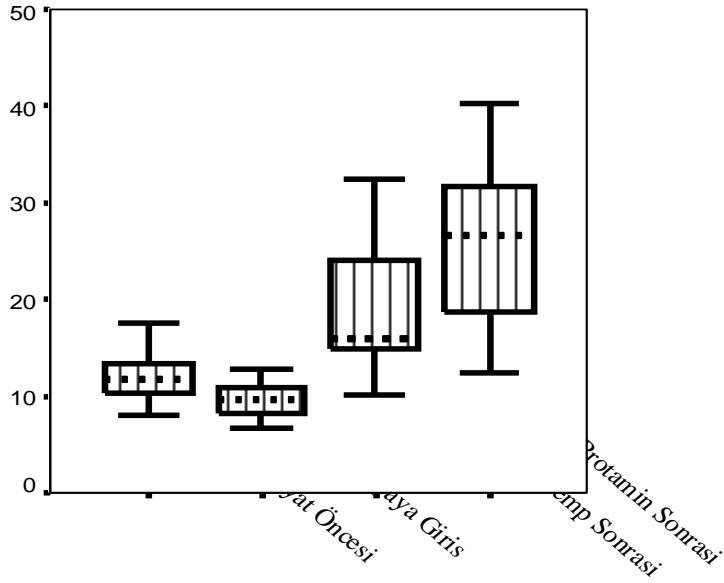

Şekil 2. Gruplar arasında TOS düzeylerinin fark, dağılım ve standart sapmaları
Aynı şekilde Pompaya giriș ile Kros Klemp sonrası ve Protamin sonrası TOS düzeyleri karşılaştırıldığında diğer gruplara göre istatiksel açıdan düşük ve ileri düzeyde anlamlı bir ilişki saptanmıștır $(\mathrm{p}<0,001)$. Kross Klemp sonrası TOS düzeyleri ile Protamin sonrası TOS düzeyleri karşılaştırıldığında düşük ve ileri düzeyde anlamlı bir fark olduğu tespit edilmiştir $(\mathrm{p}<0,001)$.

Tablo 1'e baktığımızda örneklerin içerdiği OSi düzeyleri incelendiğinde gruplar arasında anlamlı bir fark bulunmuştur $(\mathrm{p}<0,001)$. Ameliyat Öncesi ile Kros Klemp Sonrası ve Protamin sonrası örneklerin OSİ düzeyleri karşılaştırıldığında, numunelerin içerdiği OSI düzeyi diğer grupların düzeyleri ile karşılaştırıldığında istatistiksel açıdan düşük ve ileri düzeyde anlamlı olduğu tespit edilmiştir $(\mathrm{p}<0,001)$.

Tablo 1: Grupların TAS, TOS, OSİ, Seruloplazmin ve CRP düzeyleri

\begin{tabular}{|c|c|c|c|c|c|}
\hline & Ameliyat öncesi $(n=30)$ & $(n=30)$ & $\begin{array}{l}\text { Kross Klemp So } \\
(\mathrm{n}=30)\end{array}$ & $\begin{array}{l}\text { Protamin Sonra } \\
(n=30)\end{array}$ & $p$ \\
\hline $\begin{array}{l}\text { TAS, mmol Trolox } \\
\text { Equivalent/L }\end{array}$ & $0.95 \pm 0.19^{\mathrm{a}^{* * *}, \mathrm{~b}^{* *}}$ & $0.73 \pm 0.13^{\mathrm{d}^{*} \mathrm{e}^{* * *}}$ & $0.84 \pm 0.18$ & $0.92 \pm 0.14$ & $<0,001$ \\
\hline $\begin{array}{l}\text { TOS, } \mu \text { mol H2O2 } \\
\text { Equivalent/ L }\end{array}$ & $12.66 \pm 3.21^{b^{* * *}, c^{* * *}}$ & $10.22 \pm 3.28^{\mathrm{d}^{* * *}, \mathrm{e}^{* * *}}$ & $19.04 \pm 6.00^{\mathrm{f***}}$ & $25.88 \pm 8.14$ & $<0,001$ \\
\hline osí, Arbutrary Units & $1,35 \pm 0.35^{\mathrm{b}^{* * *}, \mathrm{c}^{* * *}}$ & $1.48 \pm 0.74 \mathrm{~d}^{* * *}, \mathrm{e}^{* * *}$ & $2.38 \pm 0.91^{\mathrm{f}^{*}}$ & $2.81 \pm 0.80$ & $<0,001$ \\
\hline Seruloplazmin, U/L & $\begin{array}{l}1002.48 \pm 209.20^{\mathrm{a}^{* * *}, \mathrm{~b}^{* * *}, \mathrm{c}^{*}} \\
{ }^{* *}\end{array}$ & $554.71 \pm 125.77$ & $581.92 \pm 156.67$ & $633.79 \pm 166.69$ & $<0,001$ \\
\hline CRP mg/dL & $0.85 \pm 1.44$ & $0.51 \pm 1.09$ & $0.35 \pm 0.44$ & $0.47 \pm 0.89$ & 0.291 \\
\hline \multicolumn{6}{|c|}{ Ortalama \pm Standart Sapma } \\
\hline $\begin{array}{l}\text { a. Ameliyat Öncesi ile } \\
\text { c. Ameliyat Öncesi ile } \\
\text { e. Pompaya Giriş ile P } \\
* \mathrm{p}<0,05 \\
* * * \mathrm{p}<0,001\end{array}$ & $\begin{array}{l}\text { mpaya Giriş arasında far } \\
\text { tamin Sonrası arasında fa }\end{array}$ & $\begin{array}{l}\text { k vardır. } \\
\text { ark vardır. } \\
\text { rk vardır. }\end{array}$ & $\begin{array}{l}\text { b. Ameliyat Öncesi ile Kr } \\
\text { d. Pompaya Giriş ile Kro } \\
\text { f. Kros Klemp Sonrası ile } \\
* * \text { p }<0,01\end{array}$ & $\begin{array}{l}\text { emp Sonrası aras } \\
\text { np Sonrası arasın } \\
\text { amin Sonrası aras }\end{array}$ & $\begin{array}{l}\text { fark vardır. } \\
\text { rk vardır. } \\
\text { fark vardır. }\end{array}$ \\
\hline
\end{tabular}


Aynı durumda Pompaya giriș ile Kros Klemp sonrası ve Protamin sonrası OSİ düzeyleri incelendiğinde diğer gruplara göre istatiksel açıdan düşük ve ileri düzeyde anlamlı bir ilişki bulundu $(\mathrm{p}<0,001)$. Ayrıca Kross Klemp sonrası OSİ düzeyleri ile Protamin sonrası OSİ düzeyleri karşılaştırıldığında düşük düzeyde anlamlı bir fark olduğu görülmüştür $(\mathrm{p}<0,050)$.

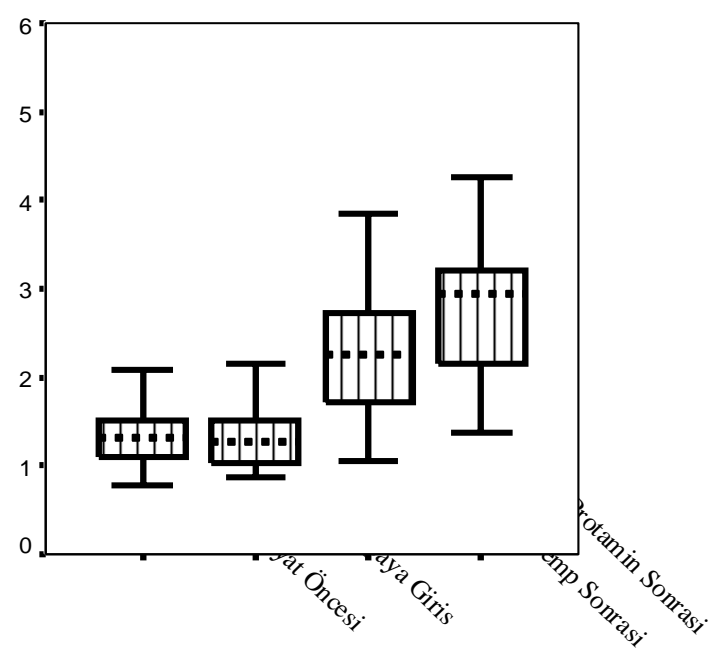

Şekil 3. Gruplar arasında OSİ düzeylerinin fark, dağılım ve standart sapmaları

Seruloplazmin düzeylerinin gruplar arasında istatistiksel açıdan anlamlı bir fark olduğu görülmüştür ( $\mathrm{p}<0,001)$ (Tablo 1'de).

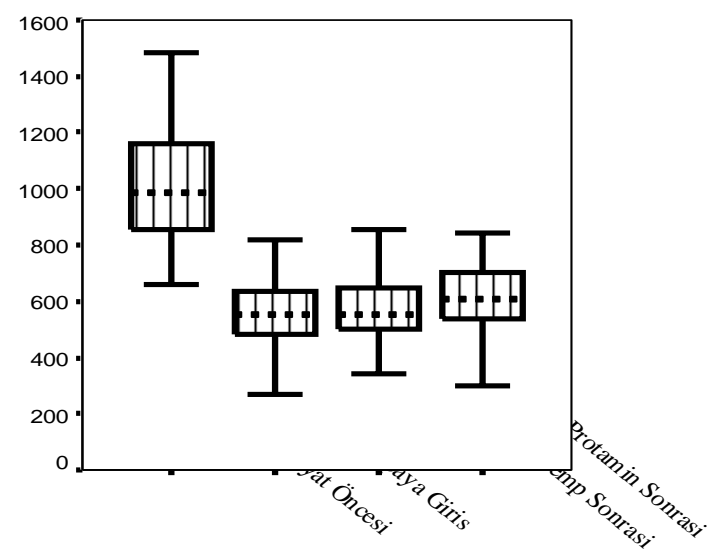

Şekil 4. Gruplar arasında seruloplazmin düzeylerinin fark, dağılım ve standart sapmaları
Ameliyat öncesi ile Pompaya giriş, Kros Klemp Sonrası ve Protamin Sonrası Seruloplazmin düzeylerini incelediğimizde, serum örneklerinin içerdiği Seruloplazmin düzeyleri diğer gruplara göre yüksek ve istatistiksel açıdan ileri düzeyde anlamlı bir fark olduğu bulunmuştur $(p<0,001)$.

Tablo 1'de de görüldüğü gibi örneklerin serum CRP düzeyleri gruplar arasında istatiksel açıdan anlamlı bir fark bulunamamıştır. Ayrıca parametreler arasında herhangi bir korelasyon bulunamamıştır.

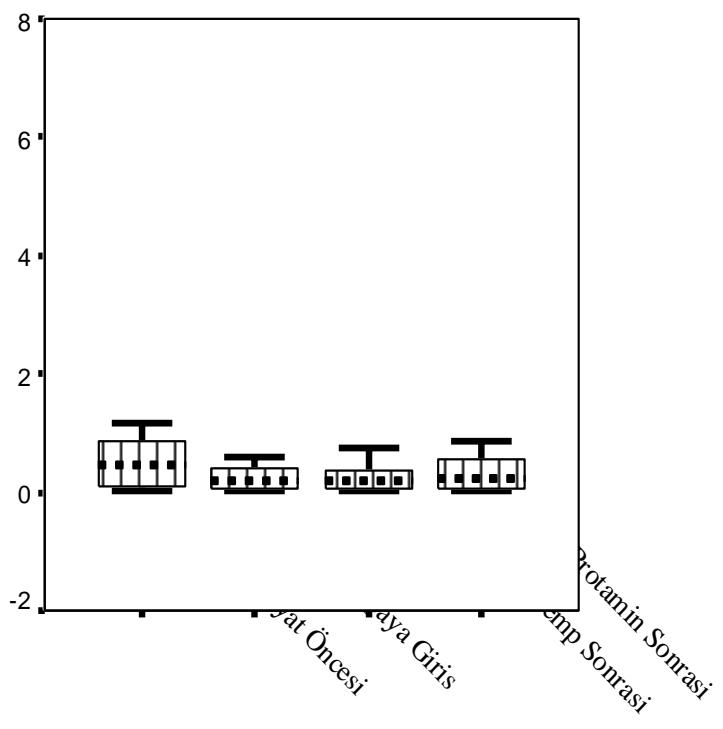

Şekil 5. Gruplar arasında CRP düzeylerinin fark, dağılım ve standart sapmaları

\section{TARTIŞMA}

Kardiyovasküler cerrahi, organ nakilleri veya aort gibi büyük damarlarda cerrahinin uygulanabilmesi için günümüzde en geçerli yol kardiyopulmoner bypasstır (KPB). Kardiyopulmoner bypassin olumlu etkilerinin yanında olumsuz etkileri de vardır. KPB ile bazı organ ve sistemlerde geçici disfonksiyon olabilmektedir. Kardiyopulmoner bypass uygulanan hastalarda oluşan yan etkilerde 4 kaskadın önemli etkisi vardır. Bu kaskadlar; fibrinolotik kaskad, koagülasyon kaskadı, 
kompleman kaskadı ve kinin-bradikinin, kallikrein kaskadıdır.

Fransen ve ark. yaptıkları çalışmada, postoperatif dönemde enfeksiyon geliflen hastalarda preoperatif CRP düzeyini diğer hastalara oranla çok yüksek bulmuşlardır ${ }^{19}$. Diğer bir çalışmada kalp cerrahisi uygulanan 100 hastada preoperatif dönemde CRP düzeyleri yüksek seyreden hastalarda postoperatif dönemde infeksiyonun sik görüldügünü belirtmişlerdir ${ }^{20}$.

Kardiyak cerrahi geçirecek olan hastalarda CRP seviyelerinin $0.5 \mathrm{mg} / \mathrm{dl}$ veya daha fazla olmasının postoperatif infeksiyon ve hastane mortalitesi için yüksek risk oluşturduğunu belirtilmiştir. Yine yüksek preoperatif CRP değerlerinin cerrahi sonrası düzelmesine rağmen kısa süre içerinde kardiyak nedenlere bağlı olarak tekrardan hastaneye yatış için bağımsız bir risk faktörü olduğu bildirilmiștir ${ }^{21}$.

KPB sırasında kanın pıhtılaşmasını önlemek amaciyla uygulanan heparinizasyon ve sonrasında heparin nötralizasyonu için kullanılan protamin, oksidatif stresi tetiklemektedir. KPB esnasında ve sonrasında başlayan immün yanıt, organ disfonksiyonuna neden olmakta ve immün yanitın başlaması ve/veya sürmesinde; katekolaminler, nötrofiller, kompleman sistemi, sitokinler, iskemi reperfüzyon sürecinde açığa çıkan serbest oksijen radikalleri, endotel hasarı ve endotoksin etkili olmaktadır.

KPB sırasında cerrahi travmaya karşı artmış sistemik proinflamatuvar yanıt gelişmesi pek çok intraoperatif ve postoperatif komplikasyona sebep olmaktadır. İnflamatuvar yanıtın başlaması ve sürmesinde yukarıda anlatılan 4 kaskad çok önemli olup, inflamatuvar yanit sonucunda en tehlikeli olanları çoklu organ disfonksiyonu ve ölümdür.

Akut faz cevabı esnasında serum seviyesi artan seruloplazminin, lipid peroksidasyonunu ve antioksidan olarak da görev yapıp serbest radikal oluşumunu önlediği düșünülmektedir ${ }^{22}$. Ayrıca seruloplazmin, ferrooksidaz aktivitesiyle demir iyonuna bağlı lipid peroksidasyonunu inhibe edebilmektedir. Ferröz demirin $(\mathrm{Fe}+2)$ ferrik demire $(\mathrm{Fe}+3)$ oksidasyonunu katalizleyerek demirin transport proteini olan transferrin ve depo proteini olan ferritine bağlanmasını kolaylaştırır ve aynı zamanda Ferik $(\mathrm{Fe}+3)$ demiri ferröz $(\mathrm{Fe}+2)$ demire yükseltgeyerek fenton reaksiyonunu da önleyerek antioksidan etki sağlar ${ }^{23,24}$.

Yapılan çalışmamızda ameliyat öncesi total oksidatif seviye (TOS) değeri pompaya giriște bir miktar düşmektedir. $\mathrm{Bu}$ düşüşün temel sebebi prime solüsyondur. KPB de prime solüsyon kullanmanın amacı; hatlar, oksijenatör ve filtrelerde bulunan havanın tahliye edilmesini sağlayarak hastaya bağlantıyı yapmak ve hemodilüsyon ile hematokrit değerini düşürerek mikro perfüzyonu artırmaktır. Ameliyat öncesinde yetişkin hastadaki kana ilaveten kullanılan prime solüsyonu nedeniyle kanda bulunan parametreler \%20-30 oranında düşüş yaşamaktadır. Ameliyat öncesi TOS değeri 12,66 iken pompaya giriște 10,22 olduğu görüldü. Pompaya giriște 10,22 olan TOS değeri kross klemp sonrasına kadar hızla artmaktadır. Bunun temel sebebi kross klemp sirasinda kalbin koroner dolaşım sistemi kesilmekte ve kan kardiyopleji sıvısı ile durdurulmaktadır. $\mathrm{Bu}$ sirada metabolik artıklar ve serbest radikaller oluşarak TOS değerinin vaka boyunca artmasına neden olduğunu gördük.

Yaplan çalışmamızda kross klempin kaldırlmasına rağmen protamin sonrasına kadarki dönemde TOS değeri sürekli artış gösterdi. Bunun temel sebebi kullanılan ilaçlar, kanın dolaştığı yabancı yüzeyler ve cerrahi prosedür olduğu düşünüldü. Yapılan bu çalışmada oksidatif stres indeksi (OSí) vaka boyunca sürekli artmıș ve protamin sonrasına kadarki dönemde yaklaşık değeri iki kat artış gösterdi. Ameliyat öncesi değeri 1,35 olan OSi 
pompaya giriște prime solüsyon kullanılmasına rağmen değerini artırarak 1,48'e çıkardı. Kross klemp sonrasına kadar koroner dolaşımın kesilmesinin etkisiyle artışa devam eden OSİ değeri protamin sonrasında en yüksek değere ulaştı.

Yaptığımız bu çalışmada total antioksidan seviyesi (TAS) ameliyat öncesi belli bir seviyede iken pompaya giriște prime solüsyonun etkisi ile belli bir miktar düştügünü gördük. Vakanın ilerleyen aşamalarında kross klemp sonrası ve protamin sonrasinda TAS sonucu artmakta olduğunu gördük. Bu durumda oksidatif strese karşı olmakta ve vücut kendi defans sistemi ile oksidatif strese karşı koruma almaktadır. Ameliyat öncesi belli seviyede olan seruloplazmin, pompaya giriş sırasında prime solüsyon ile miktarı düşmesine karşın, kros kelmp ve protamin sonrası dönemde artarak antioksidan kapasitenin artığını gördük. Ameliyat öncesi CRP seviyesi pompaya giriște biraz düştüğünü gördük. Bunun temel sebebi prime solüsyon olduğu düşünüldü. Pompaya girişten kross klemp sonrasına kadar düşüş devam etmekte, fakat bu düşüşe neyin neden olduğu konusunda yorum yapılamamaktadır. Protamin sonrasinda artan CRP değeri bu açıdan çalışmada anlamlı bir sonuç vermedi.

\section{SONUÇ}

TAS, TOS, OSI ve seruloplazmin düzeyleri gruplar arasında istatistiksel açıdan anlamlı bir fark bulundu $(\mathrm{p}<0,001)$. Serum CRP düzeyleri gruplar arasında istatiksel açıdan anlamlı bir fark bulunamadı. TOS ve OSİ değerleri pompaya girişte azalmasına rağmen kross klemp sonrası ve protamin sonrası döneme kadar sürekli arttı. TAS değeri pompaya giriște bir miktar düşmesine rağmen kross klemp sonrası ve protamin sonrası döneme kadar toparlanarak değerinin sürekli arttığını gördük.

Seruloplazmin değeri pompaya girişte düşüş yaşamış fakat kross klemp sonrası ve protamin sonrası dönemin sonuna kadar artış görüldü.
CRP değeri pompaya giriș ve kross klemp sonrasına kadar düşmüş fakat protamin sonrasında arttı̆̆ını gördük.

Bu çalışma; Harran Üniversitesi/ Şanlıurfa'da "1ST INTERNATIONAL CONGRESS ON CANCER AND ION CHANNELS" kongresinde 22.09.2017 tarihinde poster olarak sunulmuştur.

Etik Kurul Kararı: Çalışma için Klinik Araştırmalar Etik Kurulu onayı 02.07.2013 tarih 07 nolu oturum 13 sayılı kararı ile onay alındı.

Çıkar Çatışması Beyanı: Yazarlar çıkar çatışması olmadığını bildirmişlerdir.

Finansal Destek: Bu çalışma her hangi bir fon tarafından desteklenmemiștir.

Declaration of Conflicting Interests: Theau thorsdeclare that theyhavenoconflict ofinterest.

Financial Disclosure: No financial support was received.

\section{KAYNAKLAR}

1. Giachelli CM. Vasculer Calcification Mechanisms. J Am Soc Nephrol, 2004; 15: 295964.

2. Ketteler M., Bongartz P., Westenfeld R., et al. Association of low fetuin-A (AHSG) concentrations in serum with cardiovascular mortality in patients on dialysis: a crosssectional study. Lancet, 2003; 61: 827-33.

3. Merx MW., Schafer C., Westenfeld R. et al , Myocardial stiffness, cardiac remodeling, and diastolic dysfunction in calcification-prone fetuin-A-deficient mice. J Am Soc Nephrol, 2005; 16: 3357-64.

4. Lebreton JP., Joisel F., Raoult JP., et al. Serum concentration of human alpha 2 HS glycoprotein during the inflammatory process: evidence that alpha 2 HS glycoprotein is a negative acute-phase reactant. J Clin Invest, 1979; 64: 1118-29. 
5. Farzaneh-Far A., Shanahan CM., Biology of Vascular Calcification in Renal Disease, Nephron Exp Nephrol, 2005; 101: 134-8.

6. Libby P. , Atherom: More than mush, Lancet, 348 (supp l): 1996; s4-s7.

7. Niebauer J., Volk H-d, Kemp M., et al. Endotoxin and immune activation in chronic heart failure: a prospective cohort study. Lancet, 1999; 353: 1838-42.

8. Loudianos G., Gitlin JD. (2000), Wilson's Disease Sem Liv Dis, 20353-64.

9. Cross, CE., Halliwell, B., Borish, E.Tet al. Oxygen radicals and human disease, Ann. intern Med, 1987; 107: 526- 45.

10. McCord JM. , Oxygen-derived free radicals in postischemic tissue injury, N. Engl. J. Med. 1985; 312: 159-63.

11. Stocker R., Yamamoto Y., McDonagh AF et al., Bilirubin is an antioxidant of possible physiological importance, Science, 1987; 235: 4792; 1043-6. 52

12. Yiğit S., Yurdakök M., Kilin $\mathrm{K}$ ve ark., Yenidoğanlarda serbest radikallere bağlı hastalıklar, Çocuk Sağlığı ve Hastalıkları Dergisi, 1997; 39: 749-65.

13. Moison RMW., Haasnoot AA., ZoerenGrobben DV. et al., Plasma proteins in acute and chronic lung disease of the newborn, Free Radic Biol Med, 25: 3: 321-8.

14. Erel 0. (2005), A new automated colorimetric method for measuring total oxidant status, Clin Biochem, 1998; 38: 110311.

15. Erel 0. A novel automated direct measurement method for total antioxidantcapacity using a new generation, more stable ABTS radical cation, Clinical Biochemistry, 2004; 37: 277-85.
16. Aycicek A., Erel O., Kocyigit A., Increased oxidative stres in infants exposed o passive smoking, Eur J Pediatr, 2005;164:775-8.

17. Aycicek A., Varma M., Ahmet K., Abdurrahim K., Erel O. , Maternal active or passive smoking causes oxidative stress in placental tissue, Eur J Pediatr, 2011 May; 170: 645-51.

18. Erel O. Automated measurement of serum ferroxidase activity, Clin Chem, 44: 2313-9.

19. Fransen EJ., Maessen JG., et al., Enhanced preoperative C-reactive protein plasma levels as a risk factor postoperative infections after cardiac surgery, Ann Thorac Surg, 1999; 67: 134-8.

20. Ghoneim TMA., Path MRC. et al., Serial Creactive protein measurements in infective complications following cardiac operation: evalution and use in monitoring response to theraphy, Ann Thorac Surg, 1982; 34: 166-74.

21. Cappabianca G., Paparella D. et al.(), Preoperative Creactive protein predicts midterm outcome after cardiac surgery, Ann Thorac Sur, 2006; 82: 2170-8.

22. Kuralay F., Çavdar Z., İnflamatuvar Mediyatörlere Toplu Bir Bakış, Genel Tıp Dergisi, 2006; 16: 143-52.

23. Akkuş İ., Serbest Radikaller ve Fizyopatolojik Etkileri, Mimoza Yayınları, Konya. 1995.

24. Fox PL., Mukhopadhyay C., Ehrenwald E., Structure oxidant activity and cardiovascular mechanisms of human ceruloplasmin, Life Sci, 1995; 56: 1749- 58. 